\title{
EDUCATION FOR (UN)SUSTAINABLE DEVELOPMENT: RECOGNIZING ANTHROPOCENTRISM IN ROMANIA'S SUSTAINABLE DEVELOPMENT STRATEGY
}

\author{
MARIA MARTELLI ${ }^{1}$
}

\begin{abstract}
The environment is no longer a backdrop, but an agent pressing us to restructure our economic and political systems, down to our livelihoods. This research aims to make a critical overview of the Sustainable Development (SD) model. It looks at how market fundamentalism and anthropocentrism are driving forces in the shaping of its proposed form of education: education for sustainable development (ESD). This "new" educational paradigm aims to support the SD strategies that are globally implemented and "localized" at the nation-state level. The current SD model and the Agenda 2030 operate within a specific framework of the nature/culture divide, one that reiterates human domination. As such, this research aims to analyse the educational values within the idea of sustainable development - one that wishes to "reorient" society but instead ends up emphasizing it in its anthropocentric form. It does so by close reading and analysis of the UNECE Strategy for Education for Sustainable Development and Romania's National Strategies for Sustainable Development, 2008 and 2018. Concluding, it might very well be the case that restructuring schooling - and governing - to bring it up to the realities of climate change requires rethinking our fundamental educational values and the nature/culture divide, as well as making nation-states less servient of markets and less growth-oriented.
\end{abstract}

Keywords: political ecology of education, education for sustainable development, anthropocentrism, Eurocene

${ }_{1}^{1}$ Sociologist, member of the Institute for Social Solidarity, e-mail: maria.martelli@yahoo.com. 


\section{Education and its environments: the global and the marginal ${ }^{2}$}

We are the environments of others.

(Sabrina Scott, 2019)

Education changes slowly, but not as slow as a geological epoch. When it comes to environmental education, we should hope change comes fast enough. The short history of environmental education has led us to sustainable development, the latest big endeavour of global agreements. In 1992, after the Earth Summit, UNESCO replaced its International Environmental Education Program (1975-1995) with a program entitled Educating for a Sustainable Future (UNESCO, 1997). Education for sustainable development (ESD) is meant to strengthen "the capacity of individuals, groups, communities, organizations and countries to make judgements and choices in favour of sustainable development" where sustainable development is meant "to meet the needs of the present generation without compromising the ability of future generations to meet their needs" (UNECE Strategy for Education for Sustainable Development, 2005). ESD comes as one of the latest aims at institutionalizing a "broader" kind of environmental education, which has previously been a scattered concept that got defined within the debates regarding the values it should instil and the practices it should adopt (Sauve, 2005).

The notion of environmental education steadily developed, although without keeping pace with carbon emissions. Nation-states differ in how they participate in producing climate change and in how they are affected by it. They also differ in their approach to environmental education. Globally, there have been attempts at making common plans. During its 57th meeting, in December 2002, the United Nations General Assembly proclaimed the decade 2005-2014 as the "UN Decade of Education for Sustainable Development". In 2005 in Vilnius, UNECE (United Nations Economic Commission for Europe) proposed the Strategy for Education for Sustainable Development. For The Paris Agreement (2015), nation-states signed an accord to mitigate global warming and limit the temperature increase to $1.5{ }^{\circ} \mathrm{C}$. In 2015, Romania adopted the Agenda 2030 for Sustainable Development, and in 2016, at the Batumi conference, the UNECE Strategy for Education for Sustainable Development was deemed necessary for achieving the aims of Agenda 2030. This was the start of Romania's

\footnotetext{
2 This article is based on the research I have done for my master thesis at Babeș-Bolyai University, Faculty of Sociology and Social Work, coordinated by Florin Faje. I want to thank him for the conversations we had and for often sparking my curiosity. His course on Globalization and Development was instrumental for this research, as well as his insights and his helpful feedback.
} 
journey to seriously tackle environmental education - a start that begun in the context of global powers negotiations, international agreements, looming climate change and pressing biodiversity loss.

My article makes two major claims regarding ESD: its tendency to embrace market fundamentalism and its anthropocentrism. These are grounded in a close content analysis of official documents for its implementation, and particularly in the framework within which ESD operates: "sustainable development". This framework is taken as intrinsic to the perspective from which ESD is born and inseparable from it. The fundamental assumptions of sustainable development are both anthropocentric and growth-driven, as shown by close reading of their official strategy documents. Moreover, attention must also be paid to who is speaking for whom - to who has the power to define, implement and strategize sustainable development (Banerjee, 2003). In this sense, the analysis takes into account the power that some nation-states exert upon others, given the position of political marginality of Eastern Europe and thus, of Romania.

Education does not happen in an ideological vacuum, but rather in very specific geographical and historical contexts, within power structures of many kinds. Moreover, schooling is something we do with the future in mind. My aim is to contribute to the literature of the political ecology of education, to critical analysis of the sustainable development framework and to critiques of anthropocentrism by providing an overview of what education is being proposed for this uncertain and vulnerable present-future we have.

\section{The Anthropocene, The Eurocene, and the many names of development}

The new epoch of the Anthropocene has been acknowledged, albeit less so in schools, meaning that humans have affected the environment to such an extent so as to warrant the coining of a new geological categorization. While schools are slow-changing institutions, the urgency of the climate crisis (Carrington, 2019; Letters, 2019) confronts us with a lack of time to do things in the usual way. Our politics, economy, infrastructure, production, consumption, almost everything must be changed if we are to keep to a 2 degrees warming path.

This time of the "Anthropocene" has many names and carries many meanings (Bonneuil \& Fressoz, 2017). Scholars have been re-naming it ever since it was first named, to criticize or draw attention to other environment-modifying forces besides "the anthropos" (Haraway et al., 2015). Words are not innocent, and naming tends to affect how we think and approach concepts. There is a strong case for the "Capitalocene" (Moore, 2016), arguing that naming it the "Anthropocene" is ahistorical and doesn't consider what has really contributed 
most to environmental and climate change, namely, capitalism. For the purpose of better understanding the context of education for sustainable development and its implementation internationally with the help of the UNECE, the use of the "Eurocene" (Grove, 2017) name might be of help. In a similar note to the Capitalocene, the Eurocene takes into consideration the fact that "Not all of 'us' have played an equal part in the making of either the anthropos or the Anthropocene". It emphasizes the fact that there is:

... a vanguard among the European people that developed a distinctively mechanistic view of matter, an oppositional relationship to nature, and a successive series of economic systems bases indebted to geographical expansion. The resulting political orders then measured success by how much wealth could be generated in the exploitation of peoples and resources. (Grove, 2017)

The "Eurocene" draws attention to the nation-states and the peoples that have both defined and benefitted from a certain organization of the world, and thus it does a finer work of describing the context than the "Anthropocene". However, "the anthropos" is not to be forgotten as a useless category. On the contrary, it is a category that must be analysed as well, especially given the fact that it is used to define subjects worthy of political consideration - "humans". The sustainable development goals deal primarily with members of the human species and are written for their "sustainable development" first and foremost. Therefore, a definition of anthropocentrism is due, as a view that "considers the satisfaction of human interests as central" or, more clearly: "Anthropocentrism is the disadvantageous treatment or consideration of those who are not members (or who are not considered members) of the human species." (Horta, 2009)

There is an importance to be put on the naming of education for sustainable development, too. It is an education "for", "towards" something, a normative education. Its end-goal is "sustainable development", that is the sustainability of earth habitability as well as economic development - concepts that don't easily go together. In Romania, ESD translates as "educație pentru dezvoltare durabilă" - education for lasting development. "Durabil" as a word hints more to a temporal dimension, a future-projection, while "sustainable", beyond its history of use, seems to include the present as well, to argue for something that can be "sustained" now and later. In this translation, ESD's emphasis is clearly put on "development" rather than "sustainability". These word choices are to be brought up because they might impact understanding in unpredicted ways. For example, I have opted, following Hursh et al., for the use of 
EDUCATION FOR (UN)SUSTAINABLE DEVELOPMENT:

RECOGNIZING ANTHROPOCENTRISM IN ROMANIA'S SUSTAINABLE DEVELOPMENT STRATEGY

the term "market fundamentalism over neoliberalism to reflect the neoliberal's faith in markets" (Hursh et al., 2015). This belief will become transparent when reading the documents.

\section{Environmental Education after the Holocene}

Given the transformations brought about by the Anthropocene/ Capitalocene/Eurocene, how should schools be transformed? Indeed, are schools, as institutionalized forms of education, capable of being remade or are they rather part of the problem? If we are to respond, mitigate and adapt to the climate crisis, schools are to be re-shaped as well, possibly much more radically then first envisioned. We are not in Kansas anymore, not in the Industrial Revolution, not in the Holocene. Past ontological and epistemological assumptions are up for debate, now that the social/natural became visible to be as muddied as ever (Latour, 2015: 51). As a species facing a crisis it has partly helped produce (Scranton, 2015; Dawson, 2016), we owe it to ourselves and every other nonhuman to acknowledge, understand and act quickly and responsibly. This is not to re-iterate the classic argument that "growth" is a species problem, or to assume any deterministic stance regarding the human species, but rather to recognize what might be the political implications of being part of this species in particular.

There are many ways to go about this. In what follows, I will argue for a renewed understanding of our species' place within the ecosystem, based on rethinking the man/nature duality and our economic system (Morton, 2019). The environment is not just a background for our decisions. It is present, making itself known with its planetary crisis: "...when you mention the environment, you bring it into the foreground. In other words, it stops being the environment. It stops being That Thing Over There that surrounds and sustains us" (Morton, 2009: 8). What can education do in this more-than-human world, in which non-humans and other forces are pushing back the Enlightenment dream of human control and infinite progress? "What happens with education if it acknowledges that the world does not need humans, and it is likely to thrive ignorant of human existence?" (Pedersen and Pini, 2016). Re-thinking inquiry itself, and our given epistemologies, is only the first step towards restructuring schooling.

In face of the lack of recognition of how politics shape the idea of "nature" and "ecology" and "education", a political ecology of education is called for. Such a perspective is proposed by Teresa Lloro-Bidart in her analysis of the K-12 Framework for Science Education in the United States. Lloro-Bidart argues that the framework itself reproduces conceptions regarding nature/society: first, it 
emphasizes a belief in technology and science as a way of solving environmental problems and second, it frames "nature as a resource to be managed" (LloroBidart, 2015). As "part of the natural world", the framework considers students and citizens as benevolent consumers (Lloro-Bidart, 2015, pg. 138). This nature/ society division, nature as resource, and citizens as consumers are also part of the sustainable development worldview.

\section{Critiques of Education for Sustainable Development}

Sustainable development aims to solve the ecological crisis mostly by "making production ecologically sustainable" (Merchant, 2005: 283). Economist Lori Ann Thrupp (apud Merchant, 2005) sees it as split into two main camps: a northern, upper-class, scientific approach that is protectionist, aims for population control and technological innovation; and an opposing faction, composed of 'grassroots groups, indigenous peoples' movements, anti-establishment greens, urban minority groups, and a few academics, all of whom stress social justice in land, health, education, and quality of life" (Merchant, 2005: 286). We can see that ESD can be used and repurposed in a multitude of ways, both at the paperpolicy level and implementation level. However, ESD has, most probably, failed to live up to its own standards. As Huckle and Wals (2015) argue, that is partly because it was too idealistic and partly because it censored more radical critical ideas. They mount an analysis of mainstream ESD documents such as the Earth Charter aiming to show how ESD has been (1) enveloped by neoliberal discourse and (2) policy-driven, without real implementation plans:

Characterised by definitional haziness, a tendency to blur rather than lay bare inconsistencies and incompatibilities, and a cosy, but ill-considered association with the globalization agenda, the field has allowed the neoliberal marketplace worldview into the circle so the mainstream ESD tacitly embraces economic growth and an instrumentalist and managerial view of nature that goes hand in glove with an emphasis of the technical and tangible, rather than the axiological and intangible (Selby and Kagawa 2010: 37, apud Huckle and Wals, 2015).

Hursh, Henderson \& Greenwood (2015) show that environmental education (EE) had long been influenced by neoliberal ideology. First, they underline that neoliberalism is a political project, not simply an economic one.

Second, they claim that its typical policies are shown to undermine climate solutions as they "promote re-regulating society to privilege market transactions". This leads to a restricted curriculum with a specific view that favours market fundamentalism. In such a system "environmental issues and crises are turned into opportunities for entrepreneurialism and technological 
innovation, rather than a systematic political and cultural rethinking and reworking of our relationships with the environment" (Hursh et al., 2015). It is not all bleak, however. Even in such situations, not everything is determined from top to bottom, as even the often-encouraged individual green consumption can further stimulate political activism toward environmental issues (Willis and Schor, 2012 apud Hursh et al. 2015).

Kopnina (2012) provides a brief overview of the relationship between EE and ESD, showing how the two are intertwined and sometimes competing. Her main concern is that ESD "presents a radical change of focus from prioritizing environmental protection towards mostly social issues, which may or may not be related to environment" (Kopnina, 2012: 701). Moral obligation towards other species is often forgotten or put aside, while ESD's strong points are human-oriented. There is a large debate concerning whether or not education should or should not be for/towards something, and in the case in which it should, this "something" is to be discussion, pluralism, self-determination - or rather something else (Jickling, 1992; Öhman, 2006). Kopnina writes that even these multiple perspectives might be less democratic when realizing (1) what Wals and Huckle also mention, that is, the unequal power of governments and corporations in the global community and (2) that the voices of non-humans are under-represented, despite being extremely important in the crisis at hand, and even under the threat of extinction.

In a long line of environmental positions that stream from a nonanthropocentric viewpoint, I agree with Kopnina's critiques. Without arguing towards diminishing the democratic pool, but rather exactly to keep space open for yet unheard voices, I believe that education should truly dedicate itself to thinking and acting critically of the society it is born in. However, allowing continuous debate regarding whether or not we should have an education that argues for environmental and climate justice is not a radical position, but possibly a dangerous one. It might be, indeed, robbing us of the time in which we could still do something regarding both human and non-human earth habitability.

\section{Sustainable Development Strategies: political ecology at the margins of Europe}

An understanding of ESD should rest on an analysis of the framework under which it is written about and implemented: sustainable development strategies. I use the qualitative method of content analysis to look at the strategies regarding the implementation of education for sustainable development in Romania. I start with official statements such as the 2018 Voluntary National Review, Romania's National Sustainable Development Strategy 2013- 
2020-2030 (from 2008) and The Strategy for Sustainable Development Romania 2030 (from 2018) and continue with the UNECE Strategy for Education for Sustainable Development and its accompanying documents, such as the report for implementation in the 2017-2019 phase.

In the 2018 Voluntary National Review, Luminita Ghita mentions that Romania has had such a strategy dating back to 1999, under the motto "Doing more with less". After EU accession in 2007, a new strategy was devised, based on European sustainable development goals and with an agenda for 2020 and 2030. The newest strategy dates back to 2018 and is written in accordance with the 17 global SDGs. Here I will devote attention to the last two strategies to underline their inclination towards market fundamentalism and anthropocentrism.

The national sustainable development strategy (SDS) of 2008 is a prime example of situating an Eastern European country in relation to Western Europe. Romania's own goals are all traced in comparison with the European Union's, a clear sign of its attempts to try to mitigate its "deficiencies" and "underdevelopment". This is unsurprising, as:

The concept of development did not exist in its current connotation until the late 1940s, when "economic development" became associated with the process to pave the way for the replication in "underdeveloped areas" of the conditions characterizing industrialized nations (broadly, agricultural technification, urbanization, industrialization, and the adoption of modern values). (Escobar, 2015)

Sustainable development is claimed to be an "integrated policy" in which "environmental protection and long-term economic development are considered to be complementary and interdependent" (National SDS, 2008: 10 ). While defining something as complex as SD in one sentence is, of course, difficult, compressing environmental issues into "protection" and considering it "complementary" with economic development shows how the two relate ideologically: the aim is to keep the environment as healthy as possible for the greatest economic growth possible. The feasibility of this aim is clearly put to the test by the latest IPBES (2019) reports on climate and biodiversity. Were we not to question this, it would still be problematic to think of them in such a relation: one that supposes that the environment is here for (some members of) the human species to create economic development. This is more obviously stated later in the strategy, by continuously referring to nature as "capital", "resource", "service". The financialization of nature is problematic as a cultural practice, negating certain views in favour of others (Sullivan, 2009), as well as a sustainability practice, as profit for some is not livability for most. 
When we look at the four key objectives (National SDS, 2008: 12), we encounter both "environmental protection through measures that make it possible to decouple economic growth from negative environmental impacts" and the promotion of SD through the world. This is scarcely possible when looking at the ways through which the decoupling of economic growth from environmental impacts is often achieved: by increasing the service industry and other low-carbon industries in detriment of more pollutant industries which globally tend to be pushed back and externalized in the new "margins". The sustainable development paradigm operates by defining what "sustainable development" is based on the view of global powers, and implementing it in "Third World" or otherwise deemed "underdeveloped" places, without critically inquiring how these separations were made and for whose gain (Banerjee, 2003).

Romania, as a former margin or a "semiperiphery" (Boatcă, 2006), is constantly trying to gain ground by expressing the importance of its position in the EU and the resources it can bring. For example: "In terms of biodiversity Romania's accession brought into the European Union a valuable input of plant and animal species, some of them endemic, that had become extinct or rare in other parts of Europe" (National SDS, 2008: 23). This sentence shows how nature is, first, nationalized (owned by the nation to be used for its purposes) and secondly, politicized as a valuable resource that increases the country's position by Western standards. Accordingly, natural biodiversity enters the political sphere as a "resource" to advance the nation's agenda - in this case, becoming an economic and political force by European standards.

Much of the document affirms decisive belief in the mechanisms of the free market, as opposed to the difficult history of Romania's previous planned system, from which most environmental problems seem to have emerged. The document insists to "increase competitiveness" in all sectors of the economy, and "social inclusion" is to be promoted by means of a "flexible labour market, enhancing the relevance of the educational and professional training system for better employment, encouraging the emergence of entrepreneurial culture" (National SDS, 2008: 17). This flexible labour market, however, ends up taking a form that is advantageous to employers and detrimental to employees, making vulnerable those who provide "atypical" work - such as day-work, part-time, self-employed, etc. (Guga, 2016). On the contrary to helping with social inclusion, it does exactly the opposite.

Conceptually, the importance of getting "gradually closer to the average performance of the other EU countries" is continuously stressed. This is the underlying strife, often blaming Romania's historic development and comparatively praising market mechanisms: 
The main factors that have induced changes in the ecological composition and structure (and therefore in the carrying and bio-productive capacity of Romania's natural capital) in the past few decades can be traced back to the strategic objectives of socio-economic development and the means for their implementation over 1960-1989. Those policies caused imbalances and discontinuities that were corrected only in part under the spontaneous impact of market mechanisms in the period between 1990 and 2007. (National SDS, 2008:24)

The document situates Romania as an Eastern European, post-socialist country wishing to define itself according to Western European standards and to achieve them. "Market mechanisms" are, by contrast, revered, as just by their appearance imbalances are "corrected" - there seems to be no additional analysis or explanation needed. The strategy's belief in market fundamentalism is hard to deny. Romania is not a special case in this, as adhering to the "selfregulating global market" is "for Eastern European societies, ... being once again defined as "catching up" with the West" (Boatcă, 2006). The legacy of communism is shunned together with other forms of government subsidies:

...a large number of loss-making enterprises were kept alive through government interventions, which sheltered them from the rigours of market discipline and prevented them from adjusting to an increasingly competitive business environment. (National SDS, 2008:24)

Regarding education for sustainable development, the document mentions that the "entire educational and training system will internalize the principles and objectives of sustainable development" (National SDS, 2008: 82), affirming once again how it aims to be a broad, system-wide, normative approach to direct the student's view of society. These skills and knowledge will be integrated "laterally in all syllabuses", integrating them in each discipline, while aiming to transcend the boundaries of "formal, informal and non-formal". It is stressed that ESD must not be limited to an environmental perspective but be an inclusive concept that connects the environment, the social and the economic.

This approach, as previously noted (Kopnina, 2012), might end up being "a turn away from the environment", as in practice any human right, citizenship education can be catalogued as ESD. The vast area that ESD covers makes it difficult to conceptualize and can easily become useless as a category of understanding educational practice. It is easy to write about it in policies and seems to please everyone: a civil society concerned with sustainability and social injustice and a corporate sector preoccupied with economic profitability. 
However, it does not clarify what is to be done, taught or learned. Its broadness can be used as demagoguery, but it could also be used by activists, teachers, and students to pursue more localized, justice-driven, and even radical education. In that sense, ESD is a double-edged sword for maintaining political power and the economic status quo.

\section{Sustainable Development: a strategy for human and capital growth}

The newest strategy for Sustainable Development (2018) has a more independent outlook, seemingly having internalized the sustainable development goals. Sustainable development aims to "satisfy the needs of the current generation without compromising future generations" and clarifies that "no one will be left behind" (National SDS, 2018: 13). Despite such broad claims, it seems that the generations it speaks about are solely generations of the human species. Even though the strategy contains two goals on conservation of "marine" (Goal 14) and "terrestrial" life (Goal 15), many individual members of other species will, indeed, be left behind or directly consumed. These other species are conceptualized as "resources", and must not be driven to extinction based on the fact that they benefit human use and capital growth. In this sense, from the very beginning, the strategy shows its stance as anthropocentric. To be precise, its strategy is a form of anthropocentric speciesism, where speciesism is "discrimination against those who are not classified as belonging to one or more particular species" (Horta, 2010).

The 2018 SDS acknowledges that in the last ten years, Romania's SD aims were written so as to partake in EU policies. In 2018 they are written in relation to the 2015 United Nations Summit for Sustainable Development, and in light of the resolution adopted by the General Assembly, specifically, The Agenda 2030 for Sustainable Development. The new discourse is much more focused on long-term economic growth along with citizen growth as human capital. Citizens are a resource to be invested in, their resilience is something to be trained and a culture of entrepreneurship can create a space in which they are to attain their material and psychological goals (National SDS, 2018: 17). From this very beginning, it is clear that market fundamentalism is not forgotten, although the historical past and the country's position as post-socialist is not mentioned anymore. Even trust is marketized and written about in terms of "social capital" as a way of "unlocking citizen's potential for self-realization" and sustainable development of their communities (National SDS, 2018: 18). The citizen is a focus of investment of resources for profitability much more than the community itself, for the SDS's underlying theory seems to be one of 
individualism. Despite this, "community" is a core aspect of SDS, constantly mentioned although not directly supported. Protecting the environment is seen as an "opportunity" for citizens to "unite in with a noble purpose" and it is everyone's responsibility because of the "human-environment" relationship (National SDS, 2018: 18). Clearly, environmental problems are seen as important because they impact human livability, but they are also instrumentalized as an opportunity for human advancement and community-making. Not only is nature seen as for-humans, but also as a space whose protection requires human ingenuity and thus gives back enrichment. In this sense, the image of an educational puzzle is of aid: environmental problems as human-made for human purposes of self-flourishing. A circular logic is used in this paragraph, as a safe natural environment is said to be achieved by having already cultivated a sense of community (instrumental, as well, in achieving personal potential).

The aesthetics of the new strategy is different, friendlier, with graphs and colours, as if imagining a broader readership, and thus the involvement of civil society as promised. As written in relation to the global agenda, it refers directly to the 17 goals. Under goal 4 (Quality Education), ESD is mentioned as a key "instrument towards realizing SDG" and described as an underlying educational paradigm whose goals are "to help individuals reflect upon their own actions, taking into account their current and future impacts, social, cultural, economic and environmental" (National SDS, 2018: 38). Unsurprisingly, environmental is stylistically last. The 2020 goals aim at having curricula based on competences (achieved in legislation), but also, the "promotion of entrepreneurial culture" (keeping constant with its belief in market mechanisms) and the support of extracurricular activities that promote education for "health, civic education, artistic, scientific, ecologic education and through sports" (National SDS, 2018: 40). This, as a strategy, denotes that certain topics remain outside of the realm of traditional schooling (health, art, ecology), while others are pushed within (entrepreneurship). What is stressed as an aim for 2020 is schooling's ongoing connection with market actors, by encouraging knowledge-making for the necessities of the local business sector. While there is some attention paid to improving the quality of education and to addressing inequalities, little is mentioned in regards to environmental concerns. For its 2030 goals, the strategy aims to have students knowledgeable enough to "promote sustainable development", including "a sustainable lifestyle, human rights, gender equality, a culture of peace and nonviolence, appreciation of cultural diversity and of culture's contribution to sustainable development" (National SDS, 2018: 41). All of these sound good as buzzwords, but both the conceptualization of such aims and the implementation is more complicated. 
For one, it is obvious that students are to internalize the normative truths of EDS. That means not only having them agree with a growth-based, market fundamentalist, anthropocentric worldview but also to become active agents in its implementation. Students in institutionalized education are always located within a society and taught according to a society's norms and needs. While dissent might appear (from both students and teachers), the overall reproduction of a specific culture and power structure seems to be the aim.

In the 2018 Voluntary National Review, the Coordinator of the Department for Sustainable Development, Laszlo Borbely, says that "Our biggest challenge today is to live sustainable and to make sure that nobody is left behind" (quoted as written). Sustainable development is seen as a way of life that each of us, individually, should pursue. In this way, the accent is put on each individual's actions, and especially each individual's consumption. Thus, it is not rare that the proponents of such strategies focus on individuals and less so on communities, and on consumption and less so on production. Romania's position as a country is not forgotten, however, now, it is a "strategic bio-geographical position", at "the crossroads", "a bridge between ecological regions", with "the ambition to become a regional hub for sustainable development". The country's past is not mentioned anymore, only its present and its future. Environmental "riches" become part of the country's pride in the face of global powers. "Nature" has entered political discourse as a "resource" that can re-make the image of the country as strategically and geopolitically valuable.

The two sustainable development strategies (2008 and 2018) have minor differences, but broadly, they envision a future that is for-humans, for their growth, first and foremost individually, but also community-wise, nation-wise and of course, economically. This future they are preparing for seems ignorant to the implications of the climate crisis. Climate change action is only one of the seventeen goals, namely, and ironically, the 13th. The kind of education the SD strategies are promising seems very much like the strategies themselves: too optimistic, market fundamentalist, and anthropocentric.

\section{ESD and its citizens at the centre of the scorched Earth}

"The consumer is still the king: nature is not so much understood as consumed."

(Subhabrata Bobby Banerjee, 2003)

In UNECE's strategy (2005), ESD is seen as an education in a constant process of redefinition, one that must be localized, that is lifelong, and that aims to be ethical and tackle equity and solidarity issues. Community involvement and partnership making with multiple stakeholders (government, NGOs, citizens, 
private and non-private sector, mass media, etc.) is stressed and of great importance in ESD decisions. One of its principles is to promote decision making for the protection of the environment (III, point 27, UNECE Strategy for ESD 2005).

ESD's economistic, resource-oriented view, as well as the division it internally makes between human and nature transpires from parts of the strategy, although it aims to be otherwise. For one, it is said that ESD finally takes into account human action, society and economy in regards to nature, critiquing previous EE as just about environmental concerns. However, this is a dishonest view of other strands of EE, which have also included social concerns (Sauve, 2005) while being mindful of their relationship to the environment. In this sense, ESD can be accused of boasting too much and doing too little.

ESD is greatly concerned with human rights and human living - in that sense, it is anthropocentric. Some documents try to address and redress this problem, such as "The Future We Want" (United Nations Conference on Sustainable Development 2012), but most seem completely unaware or uninterested in it. For example, point 33(d) (UNECE, 2005) argues that ESD should provide insight into problems by using a life-cycle approach that focuses on economic implications as well, "addressing both the natural environment and that modified by humans" - however, in the Anthropocene it becomes harder, if not impossible, to draw a line between "natural environment" and that "modified by humans". Moreover, such a delimitation is proof of how nature is kept over-there, while humans are kept separately, over-here, as if not part of it.

Point 34 argues that governments should be "supportive of non-formal and informal learning because informed citizens and knowledgeable consumers are essential in enacting sustainability" - people are seen as both citizens and consumers, and it is through citizen practice and consumer practice that sustainability is enacted. It appears then that one's citizenship (however that may be defined) and one's status as an economic agent is what drives ESD's points. First, this denies agency to those that are not citizens, such as (1) those humans that are refugees, migrants, homeless or too poor or otherwise disenfranchised, as well as (2) to nonhumans who are not even at all considered as relevant agents, although they are the first to suffer from biodiversity loss and actions taken to sustain anthropocentric economic growth. Second, this focus on the citizen/ consumer obscures other options for sustainability (Banerjee, 2003). People might oppose viewing sustainability as simply a consumer practice, for example by wishing to create spaces outside of economic consumption (such as those of mutual exchange, urban community gardens, free zones). Of course, ESD is aimed at redressing economic inequality and social injustice, but its enactors seem to be still, mostly, the privileged ones. This is further seen in point 37 on mass-media, that should be mobilized to pass key SD messages because it is "a powerful force guiding consumer choice and lifestyles". In many cases, ESD seems to be just another instance of the individualistic mantra of "voting with our wallets". 
EDUCATION FOR (UN)SUSTAINABLE DEVELOPMENT:

RECOGNIZING ANTHROPOCENTRISM IN ROMANIA'S SUSTAINABLE DEVELOPMENT STRATEGY

\section{Making Education for Sustainable Development happen}

In terms of practice, ESD is different than "traditional schooling" (Stevenson, 2007) because it demands teachers to be a team with the students and not transmitters of information. ESD is meant to be interdisciplinary, problem-solving and process-oriented, thus it is based in the here and now, with a particularly practical approach. It is a whole-institution orientation, recommending that the entire school community (teachers, students, parents, managers) orient their teaching according to ESD principles. There is much debate on whether such a reorientation is even possible, as it requires teachers to be able (and willing) to "challenge the dominant conception, organisation and transmission of knowledge" (Stevenson, 2007). Moreover, it requires an enormous amount of work and resources to be dedicated to this restructuring.

From an implementation point of view, countries are asked to make a national plan and find or create core bodies to put it into practice. As of the 2017-2019 official report, in Romania, the Governmental institutions involved are Ministry of National Education (MoNE), Ministry of Environment, Ministry of Research and Innovation and the newly created Department for Sustainable Development (founded by Government Decision 313/2017). Additionally, three NGOs are involved: European Network for the Promotion of a Responsible Economy for the 21st Century (the REPER 21 Association), The Foundation for the Development of the Civil Society (FDCS) and The New Horizons Foundation. There are also a few universities involved and no businesses. MoNE is set as the central decision-making body, with country school inspectorates supervising implementation. ESD is cross-referenced in the formal curriculum of preuniversity education in Romania, and the National Strategy for Sustainable Development 2030 aims to achieve ESD targets. The part that is in the making is the bulk of it: Reper21's program, ONG21, which gathers NGOs under one network to draft the ESD national policy proposal by June 2019. Attention is given to informal education as well, pointing out the School in a different way (Școala Altfel) programme - one week per year, consisting of various educational activities, national contests and after-school programmes. Public awareness is mobilized, for example, through the World Environment Day 2018 (Beat plastic pollution), with selected achievements from various schools.

Reading through the report, it becomes clear that Romania is particularly late in ESD implementation, as by 2015 it should have been in stage III of its implementation, but it is only now drafting new policies and what it claims to have done is what already had been included in the national curriculums in 2017. The answer to this lateness is to be searched for, however, the difficulty of getting ESD through the institutionalized educational system isn't hard to 
notice. One can take ESD competences and try to think them through typical school practice: Learning to know; Learning to do, Learning to live together; Learning to be (Learning for the Future: Competences in education for Sustainable Development, 2011). How may these be taught in the same institution of memorization, learning to the test and constant demand for student performance (Martelli, 2018)?

The difficulties are many, which does not mean that the opportunities are few. First, the difficulty of implementing the practice of ESD, which requires challenging the way the transmission of knowledge is done, is clear. Second, the underfunding of education is a constant problem (European Comission, 2019), and it must be addressed systematically, otherwise, there is little hope for large-system change. Third, although it is anthropocentric and market fundamentalist, ESD contains claims of cultural diversity that are valuable, but vaguely implemented for example, in Romanian education, there is a lack of attention to Romani history and language (Furtună, 2019; Vasile et. al, 2020). Fourth, its championing of ideas of gender equality is as necessary as they might be met with resistance (Gheorghe, 2019; Grünberg, 2019). Fifth, the not-yet successful implementation of ESD means, for a state such as Romania, its difficulty in "catching-up" with the West and its standards. Sixth, it remains to be seen how and if ESD practices are capable of addressing the already existing systemic inequalities in access to quality education (Vasile et. al, 2020).

The opportunities to be taken from such a programme are not to be entirely dismissed, however. Re-structuring education to be less about memorizing and more about learning to be/know/do is valuable work, that can be further refined. Moreover, as previously claimed, the broadness of ESD is not always a weakness, but it could be instrumentalized by teachers, students and others to propose a more just and critical education within this same framework. However, this is not to say that all the hope should be put on the shoulders of marginal cases and lucky communities - only to acknowledge their agency. What is to be made is a call for a fundamental re-conceptualization of what education can, should, or might have to be in the age of the Anthropocene/Capitalocene/ Eurocene. Such a call cannot be made without seriously reconsidering the issues with the human/natural divide, as well as with the economic and material structures that dictate definitions and strategies.

\section{Further research questions}

This article deals mainly with the official documents of the sustainable development strategies and how they deeply influence what education for sustainable development is. In this sense, it is restricted to an analysis of 
policies, definitions, strategies, words and language, and much remains to be said about what has been done. How does ESD look within or outside the classroom is a different question. Furthermore, much remains to be said about how these documents are made and decided upon - as there might be a difference between who can speak and who ends up speaking, ultimately. In this sense, this article stands to make a few necessary claims regarding two theoretical foundations of ESD and SD, and much remains to be researched about how they are put into action.

\section{Conclusions}

Education for sustainable development is not and cannot be a replacement for environmental education. It is, more likely, an education made specifically to respond to a context of the environmental and climate crisis, without needing to radically change the system that originated the crisis. In this sense, ESD is exactly following the aims of "sustainable development" unquestioningly. It is oriented towards promoting human rights, of course, but it gives weight only marginally to the environment, which is almost an afterthought. It is an education that accounts for current issues such as infrastructures and climate change on the environment side, and poverty reduction, gender equality on the human side (as ESD itself would phrase sides as if they are separate). While it tackles world problems in a way that is transformative for how education is done in many of Romania's schools today, it is not transformative enough to look at class issues or recognize the need of justice for nonhumans. Furthermore, it leads attention away from an ecological view towards a human-centred view, therefore re-enacting what has brought us here in the first place. ESD is deeply anthropocentric and reifies a view of the world as for-humans, for human knowledge, protection, admiration, learning, growth, use. It is done in a global context of sustainable development strategies that, despite their declared intentions to reorient society towards a "sustainable" one, are still marketfundamentalist and go hand in hand with the current capitalist system.

A particular historical and economic arrangement of the human species has become the leading cause of the sixth mass extinction and climate change (Dawson, 2016; Grove, 2017), and as such, a global, political, species-conscious approach is necessary. It might be preferable, as the old saying goes, to leave much of the economistic, anthropocentric thinking that caused this mess behind, in hope of going forward. Education for sustainable development doesn't stand up to the task. Another education is possible: this might mean leaving spaces up for questioning, listening to the voices of nonhumans, having a community inspired, climate-conscious curriculum, and taking action with all of the learning community to foster resilience and solidarity with humans and nonhumans. 


\section{REFERENCES}

Banerjee, Subhabrata Bobby (2003). Who Sustains Whose Development? Sustainable Development and the Reinvention of Nature. Organization Studies 24 (1): 14380. https://doi.org/10.1177/0170840603024001341.

Boatcă, Manuela (2006). Semiperipheries in the World-System: Reflecting Eastern European and Latin American Experiences. Journal of World-Systems Research, 321-46. https://doi.org/10.5195/jwsr.2006.362.

Bonneuil, Christophe \& Fressoz, Jean-Baptiste (2017). The Shock of the Anthropocene: the Earth, History, and Us. Verso.

Carrington, Damian. (2019, May 17). Why the Guardian is Changing the Language it uses about the Environment. Retrieved https://www.theguardian.com/environment/2019/may/17/why-theguardian-is-changing-the-language-it-uses-about-the-environment.

Dawson, Ashley (2016). Extinction: a radical history. New York: OR Books.

Escobar, Arturo (2015). "Development, critiques of". In Giacomo D'Alema; Federico Demaria; Giorgos Kalis (eds.): DeGrowth. A Vocabulary for a New Era. Routledge: New York, pp. 80-87.

European Comission (2019). Education and Training Monitor 2019. https://ec.europa.eu/education/sites/education/files/document-librarydocs/volume-1-2019-education-and-training-monitor.pdf.

Furtună, Adrian Nicolae (2019). O istorie a rușinii. Discurs ideologizant între "robia țiganilor în Moldova și Țara Românească" și Sclavia romilor în spațiul românesc. In Oana Dorobanțu and Carmen Gheorghe (eds.). Problema Românească: O analiză a rasismului românesc. Bucharest: Editura Hecate, pp. 24 - 37.

Gheorghe, Carmen (2019). Cu fustele-n cap pentru feminismul rom. In Oana Dorobanțu and Carmen Gheorghe (eds.). Problema Românească: $O$ analiză a rasismului românesc. Bucharest: Editura Hecate, pp. 135 - 149.

Grove, Jairus Victor (2017). The Geopolitics of Extinction. Technology and World Politics, 204-23. https://doi.org/10.4324/9781317353836-11.

Grünberg, Laura; Rusu, Andreea; Samoilă, Elena (2019). Barometrul de gen: România 2018. Bucharest: Editura Hecate.

Guga, Ștefan (2016). Muncă Atipică în România de la izbucnirea crizei. O perspectivă de ansamblu. Bucharest: Next Publishing.

Haraway, Donna; Noboru Ishikawa; Scott F. Gilbert; Kenneth Olwig; Anna L. Tsing, and Nils Bubandt (2015). Anthropologists Are Talking - About the Anthropocene. Ethnos 81 (3): 535-64. https://doi.org/10.1080/00141844.2015.1105838.

Horta, Oscar (2009). What Is Speciesism? Journal of Agricultural and Environmental Ethics 23 (3): 243-66. https://doi.org/10.1007/s10806-009-9205-2.

Huckle, John, and Arjen E.j. Wals (2015). The UN Decade of Education for Sustainable Development: Business as Usual in the End. Environmental Education Research 21 (3): 491-505. https://doi.org/10.1080/13504622.2015.1011084. 
EDUCATION FOR (UN)SUSTAINABLE DEVELOPMENT:

RECOGNIZING ANTHROPOCENTRISM IN ROMANIA'S SUSTAINABLE DEVELOPMENT STRATEGY

Hursh, David, Joseph Henderson, and David Greenwood (2015). Environmental Education in a Neoliberal Climate. Environmental Education Research 21 (3): 299-318. https://doi.org/10.1080/13504622.2015.1018141.

IPBES (2019). Summary for Policymakers of the glob.al as.sessment rep.ort on biodiverse.ity and eco.system se.rvices of the Intergovernmental Science-Policy Platform on Biodiversity and Ecosystem Services:

https://www.ipbes.net/system/tdf/spm_global_unedited_advance.pdf?file= $1 \&$ type $=$ node $\&$ id $=35245$.

Jickling, Bob (1992). Viewpoint: Why I Don't Want My Children to Be Educated for Sustainable Development. The Journal of Environmental Education 23 (4): 5-8. https://doi.org/10.1080/00958964.1992.9942801.

Kopnina, Helen. (2012). Education for sustainable development (ESD): the turn away from "environment" in environmental education? Environmental Education Research 18(5), 699-717. Doi:10.1080/13504622.2012.658028.

Latour, Bruno. (2015). Nu am fost niciodată moderni. Cluj: Tact.

Letters. (2019, March 01). Climate crisis and a betrayed generation. Retrieved from https://www.theguardian.com/environment/2019/mar/01/youth-climatechange-strikers-open-letter-to-world-leaders.

Lloro-Bidart, Teresa (2015). A Political Ecology of Education in/for the Anthropocene. Environment and Society 6 (1). Doi:10.3167/ares.2015.060108.

Martelli, Maria (2018). The Making of Pupils: Institutionalized Education in Romanian High Schools. Studia Universitatis Babeș-Bolyai Sociologia, 63(1), 113-133. Doi:10.2478/subbs-2018-0007.

Merchant, Carolyn. (2005). Radical Ecology: The Search for a Livable World. Routledge.

Moore, Jason (2016). Anthropocene or Capitalocene? Nature, History, and the Crisis of Capitalism. PM Press.

Morton, Timothy (2009). Ecology without nature: Rethinking environmental aesthetics. Harvard University Press.

Morton, Timothy (2019). Humankind: Solidarity with Non-Human People. Verso.

Öhman, Johan (2006). Pluralism and Criticism in Environmental Education and Education for Sustainable Development: A Practical Understanding. Environmental Education Research, 12(2): 149-163. Doi:10.1080/13504620600688856.

Pedersen, Helena, and Barbara Pini (2016). Educational Epistemologies and Methods in a More-than-Human World. Educational Philosophy and Theory 49 (11): 105154. https://doi.org/10.1080/00131857.2016.1199925.

Sauvé, Lucie (2005). Currents in Environmental Education: Mapping a Complex and Evolving Pedagogical Field. Canadian Journal of Environmental Education 10 (1): 11-37.

Scott, Sabrina (2019). Witchbody. A Graphic Novel. Weiser Books.

Scranton, Roy (2005). Learning to Die in the Anthropocene: Reflections on the End of a Civilization. City Lights Books.

Stevenson, Robert B. (2007). Schooling and Environmental Education: Contradictions in Purpose and Practice, Environmental Education Research, 13 (2): 139-153. Doi: $10.1080 / 13504620701295726$. 
Sullivan, Sian (2009). “Green Capitalism, and the Cultural Poverty of Constructing Nature as Service Provider". In Steffen Böhm \& Siddhartha Dabhi (eds.), Upsetting the Offset, MayFly Books.

Vasile, Mihai; Muscă, Mădălina; Angi, Daniela; Bădescu, Gabriel; Florian, Bogdan; Țoc, Sebastian (2020). "Pisa 2018: Ce ne spun noile rezultate Pisa despre inegalitățile educaționale din România?" Institutul pentru Solidaritate Sociala, http://solidaritate-sociala.ro/wp-content/uploads/2020/06/pisa2018-v2.pdf.

\section{LIST OF DOCUMENTS}

Romania, Ministry of Environment and Sustainable Development, (2008), National Sustainable Development Strategy, 2013-2020-2030.

Romania, Department for Sustainable Development, (2018), National Sustainable Development Strategy 2030, http://dezvoltaredurabila.gov.ro/.

Romania, High-level Political Forum on Sustainable Development, (2018), Voluntary National Review, 18 July.

Romania, Ministry of National Education, (2018), Format for reporting on the implementation of the UNECE Strategy for Education for Sustainable Development (2017-2019).

The United Nations Economic Commission for Europe, (2005), Unece Strategy for Education for Sustainable Development adopted at the High-level meeting, Vilnius, https://www.unece.org/environmental-policy/education-for-sustainabledevelopment/about-the-strategy-for-esd/the-strategy.html.

The United Nations Economic Commission for Europe, (2011), Learning for the Future, Competences in Education for Sustainable Development, https://www.unece.org/fileadmin/DAM/env/esd/ESD_Publications/Compete nces_Publication.pdf.

United Nations, General Assembly, (2012), 66/288. The Future We Want. 